\title{
"Adaptation" or "Appropriation": Re-narrating the Victorian Past as an Ethical Decision
}

\author{
By Aleksandra Tryniecka*
}

"All the habits and ways of our domestic and public lives are portrayed to us in novels"

Anthony Trollope, An Autobiography: And Other Writings (246)

In the postmodern era, Kevin O'Donnell positions, "[o]ur generation is more ironically self-aware than any previous one. We realize that we are children of our time, and we play with ideas and styles from other eras quite deliberately." Hence, the progressing Victorian revival accentuates the modern "play with the past" but also, first and foremost, manifests the validity of historical recollection in the present-day era. While postmodernism conflicts with the idea of the central, unified historical narrative, it celebrates "non-linear, expressive and supra-rational discourses." Therefore, the resurrected interest in the Victorian era introduces into the post-Victorian landscape the so-far marginalized or obliterated nineteenth-century narratives. While concentrating on the literary dimension of the neo-Victorian phenomena, I present the multifaceted approaches to narrating the Victorian past. Thus, in my paper, I strive to account for the difference between the terms: "adaptation" and "appropriation" of the literary past. Simultaneously, I offer an alternative term: domestication of the past. Likewise, I investigate into the reasons for re-introducing the nineteenth-century into the modern consciousness. On the whole, my paper examines the neoVictorian literary phenomena as an ethical, deliberate and conscious choice to retell the past anew. What such a revival entails is not only the possibility of approximating the past to the current frame of socio-cultural reference, but also the hazard of reducing the Victorian era to a mere nostalgia. Moreover, as I strive to present, the so-called "Victorian values" are often turned into an umbrellaterm for an ideologised rhetoric, while "Victorian nostalgia" serves as a pretext for writing innumerable neo-Victorian "bestsellers." Hence, I examine the process of "commodification" of the past in the postmodern era. My research is based on such critical works as: Heidi Hansson's Romance Revived: Postmodern Romances and the Tradition, Louisa Hadley's Neo-Victorian Fiction and Historical Narrative: The Victorians and Us or Ann Heilmann and Mark Lewellyn's Neo-Victorianism: The Victorians in the Twenty-First Century, 1999-2009. Moreover, I discuss the techniques of reviving the Victorian past in the works of such modern writers as Syrie James and James Wilson.

\section{Introduction: The Postmodern Influence}

"Any cultural period suffers distortion from a generalized indictment, however speciously formulated. But the outlines of the Victorian era blur beyond

*PhD Candidate, Maria Curie-Skłodowska University, Poland. 
recognition in the confusion of contradictory charges," observes Jerome Hamilton Buckley in his The Victorian Temper: A Study in Literary Culture. ${ }^{1}$ Victorian culture in the present-day era, mediated indirectly through nineteenth-century literature, presents itself as a complex web of paradoxes resulting in the loose generalizations concerning the period. These, as indicated by Buckley, include such contrasting and speculative portrayals of the Victorians as: "poor," "blind" and "torn by doubt" at the same time, "at once sentimental humanitarians and hard-boiled proponents of free enterprise," believing in progress and "struggl[ing] between the force of good and the power of darkness," masculine and effeminate at the same time. ${ }^{2}$

A similar dichotomy stems from the modern commentary on Victorian literature, Buckley postulates. As he observes, "[Victorian] literature remains too purposeful, propagandistic, didactic, with too palpable a design upon the reader; yet it is clearly so romantic, aesthetic, "escapist," that it carries to posterity but a tale of little meaning" (3). Buckley's contemporary observation evokes Anthony Trollope's nineteenth-century commentary on the ambiguous nature of Victorian literature. As Trollope states in An Autobiography: And Other Writings, ${ }^{3}$

[m]y experience tells me that this community, the British reading public, is upon the whole utterly averse to the teaching of bad lessons, and will not have it. They will accept a bad work, but they reject an immoral or injurious theory of life.

The question that arises from the web of contradictory discourses is: what does Victorian literature signify in the modern times and how is Victorian culture mediated in the twenty-first century? At this point, it is indispensable to refer to the birth of the post-Victorian era that influenced the modern reattachment to the nineteenth-century.

Queen Victoria's death in 1901 signified the birth of the new historical stage: the post-Victorian era. In his Post-Victorian Britain 1902-1951, L. C. B. Seaman highlights the prominence of Victoria's reign while stating that, ${ }^{4}$

the Queen had linked the England of 1900 with the still largely rural England of the age before the Railway Mania; she had also linked England with the continent of Europe in a more personal way than has since been possible. (...) [she] in symbolic way bound England (...).

1. Jerome Hamilton Buckley, The Victorian Temper: A Study in Literary Culture (Cambridge: Cambridge University Press, 1981), 2.

2. Ibid.

3. Anthony Trollope, An Autobiography: And Other Writings, ed. Nicholas Shrimpton (Oxford: Oxford University Press, 2014), 246.

4. L. C. B. Seaman, Post-Victorian Britain in 1902-1951 (London: Taylor \& Francis, 2005), 7 . 
The growing interest in Queen Victoria's era after the departure from "modernist thought" so far disregarding the Victorian values, and the reoccurring, haunting awareness of the nineteenth-century legacy in the digital age account for the contemporary interest in the Victorian revival. Beginning from the 1950s, postmodernism paved the way for the new understanding of society and it historical indebtedness. The prefix "post" indicates a physical detachment from what is gone and directly unattainable. Simultaneously, it raises questions concerning the present relation towards the past. Postmodernism, as defined by Keith O'Donnell, "is the name given to a range of philosophical positions and aesthetic styles." 5 Rather than defined by a single theoretical framework, postmodernism argues against the notions of universalism, centrality and unified historical narratives. Hence, postmodernism responds to the Victorian "contradictory charges," as outlined by Buckley in The Victorian Temper. ${ }^{6}$ While introducing discourses raging from the historical skepticism to the constructive questioning of the nature of the so-called "truth," postmodernism strives to fill in the gap created by the post-war, embittering landscape. In the postmodern era, O'Donnell positions, "[1]ife and society become decentered; there is a marketplace of values, reasons and lifestyles on offer."7

While postmodernism conflicts with the idea of the central historical narrative, it simultaneously embraces the notion of neo-Victorianism in its multifaceted forms. The so-far omitted voices from the past, the marginalized and obliterated nineteenth-century narratives begin to flourish in the socio-cultural environment conscious of its historical heritage and yet still searching for its own cultural purpose. The post-war relativity and the rapidly growing commodification of products and even of the aforementioned "truths" and "values" contribute to the cultural quest for the bygone. The nostalgia for the "secure past," epitomized in Bakhtin's assertion that "[t]he dead are loved in different way," constitutes one of the factors in the modern investigation of the nineteenth century. ${ }^{8}$ On the other hand, there is the concurrent anxiety dominated by the feeling of "belatedness" which, according to Ann Heilmann and Mark Llewellyn, "implies creative impotence." 9 The impossibility of recapturing the past as it was thus turns into the possibility of re-narrating it in numerous potential ways that do not guarantee arriving at "ultimate truth."

5. O'Donnell, Postmodernism, 6.

6. Buckley, The Victorian Temper:, 2.

7. O'Donnell, Postmodernism, 20.

8. Mikhail Mikhailovich Bakhtin, Dialogic Imagination, ed. Michael Holquist (Texas: University of Texas, 2011), 20.

9. Ann Heilmann, \& Mark Llewellyn, Neo-Victorianism: The Victorians in the TwentyFirst Century, 1999-2009 (London: Palgrave Macmillan, 2010), 3. 


\section{Adaptation or Appropriation: Narrating the Past as an Ethical Decision}

In order to elaborate on the meaning of neo-Victorianism, it is indispensable to refer to Linda Hutcheon's A Theory of Adaptation. ${ }^{10}$ As she notices, "[w]hen we call a work an adaptation, we openly announce its overt relationship to another work or works."11 At the same time, Hutcheon argues that the value of adaptations as individual works should not be depreciated. ${ }^{12}$ Accordingly, to "adapt" means to "adjust," to "alter" or "to make suitable."13 This involves projecting an adaptation as a "transposition of particular work or works" - a "process of creation" or a "process of reception."14 Adaptation, Hutcheon posits, is necessarily a form of intertextuality. Hence, the readers respond to adaptations in individualized ways, drawing on the memories of the previous source texts. ${ }^{15}$ Therefore, adaptation seeks to engage in an interactive, dynamic exchange of narratives, memories and possibilities where each source text reveals different connotations for the various readers. Paradoxically, as observed by Heilmann and Llewellyn, "[a]daptation is by its nature an evolving form, and one which we inherited from the nineteenth century."16

Hence, while approximating the past to the modern framework of reference, one reaches for the Victorian "tools." In her work Adaptation and Appropriation, Julie Sanders links the notion of adaptation with the concept of intertextuality as well, recognizing that "[t]he impulse towards intertextuality and the narrative and architectural bricolage that can result from that impulse, is regarded by many as a central tenet of postmodernism."17 Approached from the postmodern perspective, culture and history are transformed into a "patchwork" or a collage, where a priori ideas are adapted and appropriated by means of "variation, interpretation, continuation, transformation, imitation, pastiche, parody, forgery, travesty, transposition, revaluation, revision, rewriting, echo."18 Incorporated into the list term "forgery" suggests that the quality of adaptation depends on the ethical decisions as much as on the degree of "faithfulness" to the original text.

Importantly, Sanders distinguishes between adaptation and appropriation, claiming that the latter "frequently affects a more decisive journey away from the

10. Linda Hutcheon, A Theory of Adaptation (Oxon: Routledge, 2013).

11. Ibid., 6.

12. Ibid.

13. Ibid., 7.

14. Ibid., 7-8.

15. Ibid., 8.

16. Heilmann, \& Llewellyn, Neo-Victorianism:, 244.

17. Julie Sanders, Adaptation and Appropriation (London: Routledge, 2006), 17.

18. Ibid., 18. 
informing source into a wholly new cultural product and domain."19 Similarly, for Linda Hutcheon, appropriation carries an ambiguous meaning: while it can serve as a creative adaptation, "(re-)interpretation" and ("re)creation," Hutcheon observes that it may abuse the source text as well. ${ }^{20}$ However, as she points out, "[f]or every aggressive appropriator (...) there is a patient salvager."21 This claim fully applies to the Victorian revival where the line between a playful yet ethical re-creation of the given work and its commercial exploitation appears rather thin.

As Ann Heilmann and Mark Llewellyn highlight in Neo-Victorianism: The Victorians in the Twenty-First Century; 1999-2009, an unprofessional and uncritical appropriation of the Victorian past carries numerous risks: "[w]hat contemporary adaptations of the Victorian text do (...) is utilize the precursor text as a means to reflect the ideology of the present as divorced from the past (...)," they observe. ${ }^{22}$ Furthermore, they argue that "[a]daptation of history, the media moguls suggest, is fair game in the interests of audience attraction (...)."23 Hence, Heilmann and Llewellyn perceive that the essence of appropriation lies in the issue of historical indebtedness and in the ethical treatment of the source text. As they maintain, Victorians adapted the past in order to gain knowledge about themselves rather than to rob the bygone of its substance and quality for the sake of shocking or amusing the contemporaneous audience. Victorians were "[a]nxious about their own position in the historical continuum," posits Llewellyn in his article "What is Neo-Victorian Studies."24 "The thinkers of the nineteenth century frequently turned to history (...)," he observes, "to provide sustenance to their own stability and potential."25 In Neo-Victorianism, Heilmann and Llewellyn call into question the modern author's focus on entertainment and catering for an undemanding audience, both leading to literary and historical relativism. As an example, they allude to the neo-Victorian authors: D. J. Taylor (Kept: A Victorian Mystery 2006) and Michel Faber (The Crimson Petal and the White 2002), arguing that, ${ }^{26}$

(...) adaptation can also constitute a simpler attempt to make texts "relevant" or easily comprehensible to new audiences and readerships via the process of proximation and updating. In the case of neither Faber nor Taylor are things as clear-cut as this statement might suggest, unless we take their making the Victorian (or Victorian texts) "easily comprehensible" as part of an ironic comment on the notion of appropriation as an aesthetic mode. Taylor's use of Victoriana in his novel is

19. Ibid., 26.

20. Hutcheon, A Theory of Adaptation, 8.

21. Ibid.

22. Heilmann, \& Llewellyn, Neo-Victorianism:, 235.

23. Ibid., 237.

24. Mark Llewellyn, "What is Neo-Victorian Studies?," Journal of Neo-Victorian Studies 1, no. 1 (Autumn 2008), 173.

25. Ibid.

26. Heilmann, \& Llewellyn, Neo-Victorianism:, 17 
excessive to the extreme and almost promotes the text as literally devouring the literature from which it is born on and on which it feeds. This consuming approach to the Victorian intertext posits the way in which the narrative ethics of the neoVictorian are complicated via the "theft" (read appropriation) of the structural fabric and textual characteristics from the "original" nineteenth-century novel.

While "updating" the notion of the Victorian age, one can fully deprive it of its primary qualities. Correspondingly, modern appropriations affect the perception of the Victorian literary characters, as well as they influence the projections of the nineteenth-century historical figures. In this context, Ann Heilmann and Mark Llewellyn refer to James Wilson's modern work The Dark Clue: A Novel of Suspense (2001):27

Wilson's novel confounds the distinctions between real and fictional individuals and in so doing takes biographical speculation about the lives of individuals from beyond the Victorian period and moves beyond it. (...) The fact that the "sexually aggressive element" [in Wilson's text] is portrayed in relation to a character adopted from a Victorian narrative (Walter Hartright from Wilkie Collins' The Woman in White, 1860), who commits a sexual attack on a character from the same story (Marian Halcombe), is but an example of how contemporary writers use nineteenth-century texts as an imaginative repository. What is more ethically questionable is the fact that Wilson's novel speculates on this sexual attack as a result of the influence of J.W.M. Turner, the subject of the biography Hartright has been commissioned to write. The gradual descent into madness of the central protagonist of the novel is thus drawn into an analogous relationship with the "nsanity" of the real-life Turner. This does raise ethical questions, and also aesthetic issues concerning the relationship between text and reality, and the appropriation of a historical identity for the purpose of blurring the boundaries between fiction and fact, literature and life.

Apart from the moral doubts concerning the representation of the historical figures in neo-Victorian fiction, another ethical question concerns the contemporary (unwritten, moral) rights to the Victorian texts. In The Dark Clue: A Novel of Suspense Wilson not only robs Collins' character of his initial personality, but also deliberately involves Hartright into the theme of sexual abuse. It is questionable whether such a procedure approximates one to the Victorians and whether it offers intellectual fulfillment apart from the superfluous modern delight in crime and violence. Undeniably, Wilson's novel caters for the twentyfirst century audience. However, his work exploits the past for the sake of the modern, undemanding audience.

Thus, on the one hand, adaptation and appropriation of Victorian literature can diminish or alter the value of the nineteenth-century texts while, on the other hand, the process of adaptation is capable of re-introducing a Bakhtinian,

27. Ibid., 21-22. 
constructive dialogue of voices into the present-day fiction. In his chapter "Premises on Art and Morality," John Gardner aptly argues that "(...) sophisticated modern free society tends to be embarrassed by the whole idea of morality and by all its antique, Platonic - or scholastic-sounding manifestations - Beauty, Goodness, Truth (...)."28 Gardner's claim can be used in the context of the Victorian literary revival, where numerous modern, neo-Victorian texts originate in order to cater for an undemanding audience rather than to offer one food for thought.

While appropriation has a wide spectrum of meanings, as the abovepresented examples indicate, I would like to substitute this term with domestication. The term domestication implies the acknowledgment of the bygone in the modern cultural framework; (the past finds its habitat in the present). Moreover, domestication implements the past in the contemporary literary context, while, simultaneously, accepting its original, nineteenth-century frame of reference. In this sense, the post-Victorian age recognizes the presence of the nineteenth-century discourse and strives to domesticate it in the contemporary environment, yet not necessarily own or appropriate it.

\section{Beyond Nostalgia: Filling the Cultural Vaccum}

According to Cora Kaplan, the authoress of Victoriana: Histories, Fictions, Criticism, the "new age" began to view the Victorians, ${ }^{29}$

not simply as that always selective and unreliable thing, historical memory, so easily cloyed with nostalgia or soured into persecution of the dead, but as what we might call history out of place, something atemporal and almost spooky in its effects, yet busily at work continuing this time - yours and mine - of late Capitalism.

Moreover, while depicting the Victorian revival, Kaplan recognizes the significance of the historical continuity when she asserts that "the modernist period may have increasingly replaced the Victorian as a still coercive antecedent." 30 The "pleasures and dangers" of the interest in what Kaplan terms as "Victoriana" stem from the persistent presence of the nineteenth-century objects in the postmodern environment. ${ }^{31}$ According to Buckley, the Victorians were the eager collectors of tasteless material objects: ${ }^{32}$

28. Stephen K. George, Ethics, Literature and Theory: An Introductory Reader (Oxford: Rowman \& Littlefield, 2005), 4.

29. Cora Kaplan, Victoriana: Histories, Fiction, Criticism (New York: Columbia University Press, 2007), 56.

30. Ibid., 6.

31. Ibid.

32. Buckley, The Victorian Temper:, 131. 
[a]ll levels of bourgeois society exercised their acquisitive powers at leisure moments in amassing great stores of bric-a-brac, wax flowers, ormolu candelabra, porcelain vases, plaster busts of literary idols, and iron or lead statuettes of pagan deities. For the sheer joy of possession, they accumulated innumerable oddments, especially novelties in glass (...).

Alongside with the nostalgia-awakening items and Victorian pieces of architecture residing in our presence, Kaplan recognizes the subsistence of Victoriana in "a film, a pastiche, fiction, a retro style, even a biography." 33 Therefore, Victoriana have become a breeding ground for the postmodern arts and media. In Neo-Victorianism, Mark Llewellyn and Ann Heilmann allude to the numerous examples of "Victorianising" the presence, including the expansion of "theme parks" such as "the Great Victorian Theme Park" or "Dickens World."34 They also refer to the figure of Andrew Davies, a Welsh screenplay writer, whose "identity as an adaptor of nineteenth-century, particularly Victorian contexts has made him a cultural authority on the Victorian and neo-Victorian literary spheres." 35 The visualized theme parks and state-of-the-art cinematic adaptations bear witness to the development of what Graham Allen names as "technological society." 36 Hence, while adapting the Victorians, we reformulate ourselves. "Technological society," Graham Allen observes, "(...) is dominated by reproductions of original works." 37 The mass production of videos and movies, the expansion of photography, books, e-books, paintings, drawings and semioriginal objects enhances the experience of the Victorian past and, at the same time, makes one ignorant of the "actual" nineteenth-century context. Postmodernism, as Allen posits, defines itself as the age of reproduction, reenactment, mimicry and renewal. Hence, while filling the cultural vacuum with the nineteenth-century replicas and artefacts, postmodernism embarks on the quest for its own identity. However, while recreating the Victorian presence by means of arts and media, one carries an ethical responsibility not only towards the current age, but mainly towards the past. The past serves as the only authentic means for reasserting the presence. Nevertheless, in this reassertion, the past cannot be abused. A manifestation of such an ethical responsibility can be found in the neo-Victorian ficiton, as I will strive to present in the following part of my work.

33. Kaplan, Victoriana: Histories, Fiction, Criticism, 3.

34. Heilmann, \& Llewellyn, Neo-Victorianism:, 213-214.

35. Ibid., 237.

36. Graham Allen, Intertextuality (London: Routledge, 2000), 181.

37. Ibid., 181-182. 


\section{Neo-Victorian Biography and its Ethical Value}

"Neo-Victorian fiction," Louisa Hadley indicates, signifies bidirectionality: it "attempt[s] to narrate the Victorian past" and "explore[s] the ways in which the past has been narrated in the present."38 Furthermore, neo-Victorian fiction embraces "the possibility of establishing an empathic connection to the past without resulting in presentism." 39 This empathic connection appears paramount in the study of the neo-Victorian genre that seeks to revisit the past from a dialogical perspective. Moreover, as mentioned above, the postmodern Victorian revival signifies the quest for the contemporary identity. In this respect, neoVictorian works constitute an attempt to create a modern narrative - the contemporary "biography" of the postmodern times, the postmodern authors and readers.

The most enthusiastically revived nineteenth-century genres encompass biographies and detective novels. While experimenting with the Victorian "Life and Letters" mode of writing, ${ }^{40}$ the modern authors address the issue of "biographical truth." For example, Syrie James' The Secret Diaries of Charlotte Brontë (2009) propounds a fictional autobiography of the nineteenth-century authoress. In the preface to James' work one reads:41

Dear Reader,

Imagine, if you will, that a great discovery has been made, which sparked enormous excitement in the literary world: a series of journals, which have lain buried and forgotten for more than a century in the cellar of a remote farmhouse in British Isles, have been officially authenticated as the private diaries of Charlotte Brontë. What would those diaries reveal?

The preface to James' novel prepares the reader for the encounter with the fictional autobiography. Besides, it builds expectations towards the text while drawing on the idea of discovery and revelation. The preface alludes to Brontë's writing mode as well, intimately addressing the "Dear Reader" and setting the scene for exclusivity and secrecy. The implication that the novel contains an enigmatic record from Charlotte Brontë's life not only challenges the "Life and Letters" biographical mode, but also explores the possibility of the alternative narratives of the past. The aim of Syrie's experiment with the text lies in proposing a vision of Brontë's life that steps aside from the dominant

38. Louisa Hadley, Neo-Victorian Fiction and Historical Narrative: The Victorians and Us (New York: Palgrave Macmillan, 2010), 26-27.

39. Ibid., 26.

40. Ibid., 36.

41. Syrie James, The Secret Diaries of Charlotte Brontë (New York: Harper-Collins, 2009), vi. 
biographical discourse. Hence, The Secret Diaries stand in the shadow of such texts as: Elizabeth Gaskell's The Life of Charlotte Brontë (1857), Winifred Gérin's Charlotte Brontë: The Evolution of Genius (1967) or Rebecca Fraser's Charlotte Brontë: A Writer's Life (2003). At the same time, James' work instigates a successful polemic with the past, approximating it to the reader's zone through the first person narration. Reading the "mysterious diary" allows one not only to recognize in Brontë a famous writer, but also a "real" woman. Hence, James' text fulfills the desire to picture the Victorians just like us. Meanwhile, James' work does not alter Brontë's biography but offers the first-person narrative possibility that enriches one's vision of Charlotte's life as a woman writer. James' empirical writing encourages the empathic reflection over history and historical figures. It domesticates the past and approximates it to the reader's contemporary zone.

Apart from Syrie James, other modern writers eagerly pursue the idea of "fictionalizing" Charlotte Brontë's biography, treating her life as the repository for ideas. For instance, Laura Joh Rowland attempts to revisit the Brontë narratives in her The Secret Adventures of Charlotte Brontë (2008) and Bedlam (2010). In Rowland's works, Brontë appears suspended between "reality" and fiction, witnessing crime, murder and conspiracy. In order to create the effect of biographical veracity, Rowland enables Brontë to relate her "own" story. While Roland's work is a conscious pastiche experimenting with the historical narrative, it also raises ethical questions regarding Brontë as a historical figure: to what an extent is it justified to alter one's biography and what is the purpose of such a revision? Moreover, how does Roland's novel enrich the general cultural understanding of the Victorian past? While creativity serves in neo-Victorian fiction as a major modus operandi, it is also the ethical framework that should be acknowledged by the modern authors, especially in the times when the figures such as Brontë, Thackeray or Dickens gradually become oblivious to the younger readers. The task of the neo-Victorian fiction lies in the creative and meaningful re-telling of the past rather than in its creative misuse. The multidimensional postmodern narratives constitute an experiment whose task lies in the possible approximation to "historical truth" but not in its ultimate denial. The postmodern emphasis on the multifacetedness of literary "truth" does not release the modern authors from the ethical obligation towards history and historical figures residing in the past. Hence, as it appears to me, in the context of the Victorian literary revival, "multifacetedness" does not entail "relativism." While Neo-Victorian literary interests essentially entail historical revival, they simultaneously embrace the notion of the "narrative experiment," but never the concept of meaningless relativism. Importantly, the interest in history distinguishes neo-Victorian literature from numerous postmodern literary genres, ultimately relying on parody and pastiche. 


\section{Conclusion: Reviving the Roots, Finding the Common Ground}

"An important problem which is shared by many writers of fiction today is how to make it possible to create meaning when there are neither common value systems not common cultural beliefs to lean on," postulates Heidi Hansson in Romance Revived. Postmodern Romances and the Tradition. Furthermore, she introduces the idea of the "postmodern romance" as the universal "common ground" between the authors and the readers:42

[t]here is an urgent need for both writers and readers to find common ground, otherwise communication through literature runs the risk of becoming impossible and obsolete. Postmodern romances capitalize on the popularity and familiarity of the romance to create this common ground, which means that the works have to be recognisable as romances.

Hence, postmodern romances serve as the generic, common framework of reference for the domestication of the literary past. Paradoxically, the postmodern interest in revisiting and domesticatingvthe Victorian era, also by means of the "postmodern romance" framework, stems from the temporal detachment from the past. According to Louisa Hadley, the Victorians appear attractive to the postmodern audience as they are removed from the direct sphere of influence and yet they are still located within a historical vicinity.

Rachel Hollander, in her Narrative Hospitality in Late Victorian Fiction: Novel Ethics, argues that "(...) most of the mid-Victorian commentaries on the morality of fiction seem to test the values of particular novels against a common sense of English standards." 43 The recurring interest in the Victorian works attests the enduring relevance of these nineteenth-century standards in the present-day world. Moreover, Victorian socio-cultural norms appear attractive and interesting to test in the twenty-first century context, as they are located in a temporal distance from our era.

The Victorian period, removed from the sphere of the direct contact with the present, constitutes a spectral background for postmodern reality. This assertion can be supported by Mark Llewellyn's claim that, ${ }^{44}$

the approaches required to reading the neo-Victorian and do it critical justice are exactly the same mix of contextual and textual awareness required to address the multiplicity of the Victorians themselves. (...) [t]he Victorian and neo-Victorian offer the simultaneous possibilities of proximity and distance.

42. Heidi Hansson, Romance Revived. Postmodern Romances and the Tradition (Uppsala: Swedish Science, 1998), 3.

43. Rachel Hollander, Narrative Hospitality in Late Victorian Fiction: Novel Ethics (New York: Routledge, 2013), 26.

44. Llewellyn, "What is Neo-Victorian Studies?," 175. 
Arguing along these lines, it seems that the distance from the Victorian era increases the chances of a multifaceted modern revision. According to Cora Kaplan, we are enchanted by the Victorians because the "distant" signifies the "antique" and "exotic:"45

(f)or while the high literary modernism and the popular culture in the first half of the twentieth century defined itself through an explicit or tacit rejection of the cultural preferences and social mores of the Victorian world, distance from the period had not only produced detailed - and controversial - historical analyses of its customs, practices and influence, but has gradually lent it over time the charm of antiquity and the exotic, so that increasingly, in the new millennium, even its worst abuses seem to fascinate rather than appall. Genealogically speaking, the Victorian is no longer seen as a disapproving parent of the louche modernity of the opening of the last century (...).

Hence, the presence opens up with the new literary possibilities which are persistently embedded in the past. While domesticating the literary past, the modern reader embarks on the quest reviving the historical continuity. As Kevin O'Donnell positions, "[o]ur generation is more ironically self-aware than any previous one. We realize that we are children of our time, and we play with ideas and styles from other eras quite deliberately." ${ }^{46}$ However, what is fundamental, the modern "play with ideas" should be always located within the ethical boundaries - for the sake of the bygone and for the sake of the present day.

\section{Bibliography}

Allen, Graham. Intertextuality. London: Routledge, 2000.

Bakhtin, Mikhail Mikhailovich. Dialogic Imagination, edited by Michael Holquist. Texas: University of Texas, 2011.

Buckley, Jerome Hamilton. The Victorian Temper: A Study in Literary Culture. Cambridge: Cambridge University Press, 1981.

George, Stephen K. Ethics, Literature and Theory: An Introductory Reader. Oxford: Rowman \& Littlefield, 2005.

Hadley, Louisa. Neo-Victorian Fiction and Historical Narrative: The Victorians and Us. New York: Palgrave Macmillan, 2010.

Hansson, Heidi. Romance Revived. Postmodern Romances and the Tradition. Uppsala: Swedish Science, 1998.

45. Kaplan, Victoriana: Histories, Fiction, Criticism, 6.

46. O’Donnell, Postmodernism, 29. 
Heilmann, Ann, \& Llewellyn Mark. Neo-Victorianism: The Victorians in the TwentyFirst Century, 1999-2009. London: Palgrave Macmillan, 2010.

Hollander, Rachel. Narrative Hospitality in Late Victorian Fiction: Novel Ethics. New York: Routledge, 2013.

Hutcheon, Linda. A Theory of Adaptation. Oxon: Routledge, 2013.

James, Syrie. The Secret Diaries of Charlotte Brontë. New York: Harper-Collins, 2009. Kaplan, Cora. Victoriana: Histories, Fiction, Criticism. New York: Columbia University Press, 2007.

Llewellyn, Mark. "What is Neo-Victorian Studies?." Journal of Neo-Victorian Studies 1, no. 1 (Autumn 2008).

O’Donnell, Keith. Postmodernism. Oxford: Lion Publishing Plc, 2003.

Seaman, L. C. B. Post-Victorian Britain in 1902-1951. London: Taylor \& Francis, 2005.

Sanders, Julie. Adaptation and Appropriation. London: Routledge, 2006.

Trollope, Anthony. An Autobiography: And Other Writings, edited by Nicholas Shrimpton. Oxford: Oxford University Press, 2014. 
